University for Business and Technology in Kosovo

UBT Knowledge Center

Nov 2nd, 9:00 AM - Nov 3rd, 5:00 PM

\title{
The case of Albanian Banking Sector impact of Capital Investments in the Hotel Industry: A Survey of Croatia
}

Jonika Kromidha

University of Tirana, kromidha@yahoo.com

Follow this and additional works at: https://knowledgecenter.ubt-uni.net/conference

Part of the Business Commons

\section{Recommended Citation}

Kromidha, Jonika, "The case of Albanian Banking Sector impact of Capital Investments in the Hotel Industry: A Survey of Croatia" (2012). UBT International Conference. 56.

https://knowledgecenter.ubt-uni.net/conference/2012/all-events/56

This Event is brought to you for free and open access by the Publication and Journals at UBT Knowledge Center. It has been accepted for inclusion in UBT International Conference by an authorized administrator of UBT Knowledge Center. For more information, please contact knowledge.center@ubt-uni.net. 


\title{
Critical view on Relationship Marketing and Corporate Customers Satisfaction The case of Albanian Banking Sector
}

\author{
Jonika Kromidha $^{1}$ \\ Faculty of Economy, University of Tirana, Albania, \\ kromidha@yahoo.com
}

\begin{abstract}
The purpose of this paper is to analyze, in the frame of doctorate research, findings related to relationship marketing and customer satisfaction "case of Albanian Banking Sector" focused at corporate customers. The main aim is to gain an understanding of what relationship marketing is and to analyze the advantages of relationship marketing for banking sector and its implementation in parallel with corporate customers' perception.

There is a need for better strategies in the banking sector. As a result of increase in competition, establishing a long-term institutional relationship with corporate clients becomes of great importance to the banks in order to gain a moderate or greater share of the financial market and of a corporation's business. Since corporate customers are key players in economy it is imperative their perceptions of relationship marketing implementation.
\end{abstract}

Keywords: Relationship Marketing, Corporate Customers, Banking Sector 